\title{
AN ASSESSMENT OF RFID APPLICATIONS IN MANUFACTURING COMPANIES
}

\author{
Bartłomiej Gładysz \\ Warsaw University of Technology, Institute of Production Systems Organization, Poland \\ Corresponding author: \\ Bartlomiej Gladysz \\ Warsaw University of Technology \\ Institute of Production Systems Organization \\ Narbutta 86, 02-524 Warszawa, Poland \\ phone: (+48) 22 2348123 \\ e-mail: b.gladysz@wip.pw.edu.pl
}

Received: 5 December 2014

Accepted: 22 January 2015

\begin{abstract}
The meaning of Cyber Physical Systems and an Internet of Things with indication of RFID position in those concepts was outlined. Research program related to assessment of RFID technology was presented. Author deducted on problems related to RFID implementations and RFID essentially for logistics of manufacturing companies. Research goals and problems were formulated. Tools, techniques, models and methods that could be utilized were proposed and discussed. Research was focused on design of a new method to support early decision making phases for RFID application in logistics of manufacturing companies. Author stated that literature and practice lacks of complex method to answer if RFID is strategically important for the company, which processes should be RFID-supported, how RFID-supported processes should be designed and if RFID-support is rational. Framework for assessment of RFID technology with illustrative example was discussed.
\end{abstract}

KEYWORDs

Cyber-Physical Systems, RFID, decision making, Assessment of RFID Technology (ART).

\section{Introduction}

"When wireless is perfectly applied the whole earth will be converted into a huge brain, which in fact it is, (...) and the instruments through which we shall be able to do this will be amazingly simple compared with our present telephone. A man will be able to carry one in his vest pocket." - Nikola Tesla, 1926 [1].

Almost 90 years ago Tesla predicted, what we are experiencing nowadays. He was talking about wireless devices communicating with each other, but also emphasized the role of computation process ("huge brain").

The term "Cyber-Physical Systems" (CPS) appears more and more frequently in literature over past ten years. By this expression researchers describe integration of computation and physical processes [2]. Embedded units are used to control physical processes, often based on a data gathered from controlled processes through sensor networks. The other popular and similar to CPS concept is the Internet of Things (IoT) [3]. While CPS focuses more on integration of cyber world (Internet) and physical world, IoT is more about interactions in physical world for ubiquitous connection. There is still no clear differentiation between those concepts, but there are works focusing on definition and relation between CPS, IoT, WSNs (wireless sensor networks) and M2M (machine-to-machine communication) e.g. [4]. Authors of [4] propose to define CPS as "an evolution of M2M by the introduction of more intelligent and interactive operations, under the architecture of internet of things (IoT)". IoT may be also defined as a network of CPSs. Preferences on the use of CPS or IoT term are also dependent on who is speaking, so e.g. Chinese and academia generally prefer IoT, when Americans and government CPS (see [5]). When analyzing similarities and differences between CPS and IoT, Schilberg concluded that they share vision and 
core technology and have distinct scientific community, philosophy and focus, but today for all practical purpose are more or less synonyms [1].

There is growing number of CPS concept adoption. Networked machines are more valuable than isolated ones, because they can interoperate and algorithms could be more holistic. Nowadays machines can collect huge amount of data from various networks through WSNs. U.S. President's Council of Advisors on Science and Technology [6] recommended to continue investments in CPS research because of its grand potential impact on a number of critical sectors (energy, aerospace, automotive, civil infrastructure, healthcare, manufacturing, and transportation).

One of the technological options for identification of physical objects is RFID (Radio Frequency Identification). The CPS topology including RFID was proposed in [7]. According to [8] RFID system, considered not only as technology and hardware itself but also as a software and logic components, is typical CPS, because it includes:

- computational element (computing and dataprocessing functions of readers and postprocessing system),

- controlling element (usually a RFID system is under the control of a specific controller),

- communication element (radio frequencies are used for information exchange, as well as for data and controlling flows).

RFID system is never stand-alone solution, but it is always integrated or connected with other systems. Those systems could be as well cyber, as physical in its nature. For example RFID system could be integrated with conveyor belt automation system and send data to information system of a company (e.g. ERP or WMS).

\section{Research problem}

"Calling RFID a radio bar code is like calling a car a motorized horse" - K. Ashton, co-founder of MIT AutoID Center.

\section{Identification of objects in supply chain}

Identification of objects in supply chain is:

- essential/important from informatics, organizational and economy point of view in relation to processes in supply chains, what particularly concerns manufacturing companies,

- essential/important part of communication process in supply chain, especially in terms of reliable encoding and decoding object's data.
Information flow should be possibly accurate with objects' flow (without delays and errors). Identification of objects and consecutively information flow could be performed manually, but in industrial environment usually technology is used to automated identification tasks, as they are time-consuming and do not create value added. Most commonly used technology is bar coding, but radio frequency identification is also getting more and more popular especially among industry leaders and companies that face problems of high intensity objects' flow and objects' variability.

Information flow is exposed for numerous noises that could distort object's data. Application of improper technical and technological means for identification process could lead to increase of its duration, costs and occurrence of faults. In opposition, proper performance of identification process leads to increase of efficiency of supply chain through elimination of noises impacting communication and stronger integration of objects' flow with information flow.

\section{Radio frequency identification}

One of technologies to support and automate identification is radio frequency identification. It is dynamically developing and innovative, especially considering economy of Poland [9, 10].

Every time when radio frequencies $(\mathrm{RF})$ are used to identify and/or locate tagged object, author calls RFID technology. RFID technology is each technology based on RF and enabling the process of identification and/or location. Detailed description of physics and applications is subject of many publication e.g. [3, 11-13]. RFID is the technology that offers wide spread of applications for manufacturing companies. Its applications are not limited to predefined use cases and RFID is not only next autoidentification technology, better and faster than barcodes. RFID also enables dramatic changes in business processes that could be performed in a way previously impossible due to technology limitations. The subject of a research will be RFID applications in logistics processes, both external and internal, of manufacturing companies. Author follows relabeling perspective on logistics versus supply chain [14].

Numerous authors reported benefits of RFID applications. Benefits can be found e.g. in production logistics [15], warehousing [16], external supply chains [17]. At the same time authors report difficulties in return on investment calculations and high costs. It means that RFID implementation needs to be preceded by detailed analysis. Radio Frequency Identification (RFID) is the technology that could eliminate inefficiencies and delays in communication 
process, but RFID applications could not bring effect with expected benefits and be not economically effective [18].

As every innovative technology RFID needs detailed analysis before application. Analysis should be conducted in terms of choice of application area and potential benefits. It should be found method to evaluate potential of RFID-based improvements, to choose processes for improvement or reengineering. RFID application in manufacturing company brings several problems to analyze, discuss and solve. Prob- lems could be divided into few groups (see Fig. 1). Brighter-colored problems will be the subject of research. These are namely: initial decision and business processes design or reengineering.

Table 1 shows list of selected papers on design, implementation and evaluation of RFID solutions for logistics processes. There were no papers found that treat about strategic decisions indicating: if RFID should be considered, which and how processes should be improved and what will be the expected effect of changes.

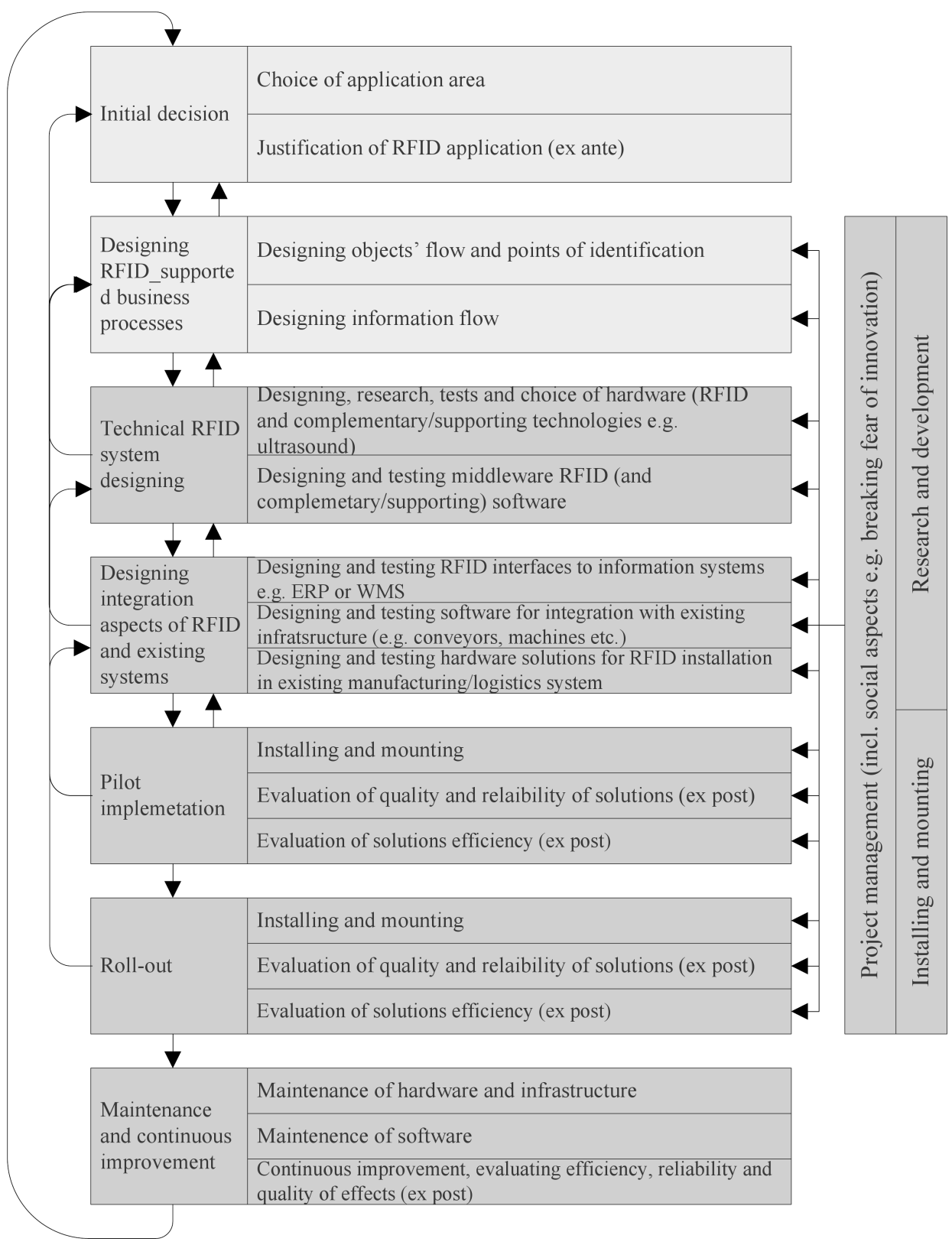

Fig. 1. RFID application problems (source: own work). 


\section{Table 1}

Selected papers on design, implementation and evaluation of RFID solutions for logistics processes.

\begin{tabular}{l|l}
\hline Ref. & \multicolumn{1}{c}{ Subject } \\
\hline$[19]$ & $\begin{array}{l}\text { Design of business processes for supply chain } \\
\text { using RFID - support for implementation of } \\
\text { supply chain management information system }\end{array}$ \\
\hline$[20]$ & $\begin{array}{l}\text { Design and evaluation RFID system, SCOR- } \\
\text { based integration of infrastructure with man- } \\
\text { ufacturing system }\end{array}$ \\
\hline$[21]$ & $\begin{array}{l}\text { Design of sophisticated and innovative RFID } \\
\text { solutions }\end{array}$ \\
\hline$[22]$ & $\begin{array}{l}\text { Design of RFID systems as IT innovations - } \\
\text { based on general framework for "mindful IT } \\
\text { innovation" }\end{array}$ \\
\hline$[23]$ & $\begin{array}{l}\text { Analysis of benefits and barriers of RFID im- } \\
\text { plementation based on literature review and } \\
\text { questionnaire surveys }\end{array}$ \\
\hline$[24]$ & $\begin{array}{l}\text { Justification of RFID implementation - very } \\
\text { high generalization level }\end{array}$ \\
\hline$[25]$ & $\begin{array}{l}\text { Evaluation of RFID impact on processes } \\
\text { based on authors reference model of processes } \\
\text { and benefits }\end{array}$ \\
\hline$[26-28]$ & $\begin{array}{l}\text { Evaluation of RFID implementation benefits } \\
\text { in supply chain of selected market and branch }\end{array}$ \\
\hline$[29,30]$ & $\begin{array}{l}\text { Evaluation of RFID implementation benefits } \\
\text { in supply chain - case study }\end{array}$ \\
\hline$[17]$ & $\begin{array}{l}\text { Evaluation of RFID implementation benefits } \\
\text { in supply chain - literature review of case } \\
\text { studies (ex post evaluation) and methods for } \\
\text { justification (ex ante) }\end{array}$ \\
\hline$[32]$ & $\begin{array}{l}\text { Evaluation of RFID benefits based on simula- } \\
\text { tion model }\end{array}$ \\
\hline$[34]$ & $\begin{array}{l}\text { Evaluation of RFID benefits based on analyt- } \\
\text { ical models }\end{array}$ \\
\hline $\begin{array}{l}\text { Evaluation of RFID benefits based on litera- } \\
\text { ture review, case studies and critical success } \\
\text { factors }\end{array}$ \\
$\begin{array}{l}\text { Evaluation of RFID implementation based on } \\
\text { simulation }\end{array}$ \\
$\begin{array}{l}\text { Evaluation of RFID potential impact based } \\
\text { on SCOR }\end{array}$ \\
\hline effectiveness \\
\hline$[36]$
\end{tabular}

Analyzed works allow for evaluation of specific solutions, classification of benefits in different application areas (especially in supply chains), indication of relations of qualitative benefits and measurable factors, evaluation in terms of characteristics of specific economies, branches and markets. All the authors conclude that RFID is promising technology that eliminates numerous dysfunctions of communication processes in supply chains and is implemented successfully for logistics processes in many branches. At the same time authors emphasize the need of detailed pre-implementation analysis and calculations of investment profitability. Starting point for the research was the output of $[35,36]$, as those papers treat about preliminary evaluations of RFID implementation, but are limited and lack of:

- indication which processes should be improved, how to improve/reengineer processes, what will be the effect of changes,

- emphasis on manufacturing processes - they focus on sourcing and delivery processes, so they are not suited for manufacturing companies,

- issues related to business process modelling, reengineering,

36 ; considerations on how to choose process for improvement - it enables ex post evaluation,

35 ; details and indication how to transpose from strategic to tactical level.

Literature lacks of research and synthetic, factory-level methods to solve problems related to design of RFID solutions on consecutive levels of strategy, tactics, operations and evaluation. Design of 4-steps ART (Assessment of RFID Technology) method to analyze RFID potential applications in logistics processes of manufacturing company is the main subject of research.

\section{Hypothesis, goals and research questions}

Information flow should be possibly accurate with objects flow (without delays and deformations). Identification of objects and consecutively information flow could be performed manually, but in industrial environment usually technology is used to automate identification tasks, as they are time-consuming and not creating value added. Most commonly used technology is bar coding, but radio frequency identification is also getting more and more popular especially in industry leaders and companies that face problems of high objects flow and objects variability.

Decision on RFID application has strategic importance for a company, because:

- may determine strategic advantages, based on expected benefits substantial from informatics, organizational and economy point of view in relation to processes in supply chains, what particularly concerns manufacturing companies (see references in Table 1), in categories of increase of supply chain transparency, through increase of data reliability and on-line accessibility leading to better management of supply chain and stocks, acceleration of processes in supply chain, through acceleration of objects' identification and faults' elimination,

- has significant impact on technological environment as needs integration with other technologies (including internal transport, IT, machines etc.),

- is directly linked with processes redesign or reengineering,

- needs significant investments. 
Application of RFID should be preceded by evaluation of its innovative potential, choice of the area for application, scale and scope of changes related to it, as well as evaluation of implementation effects (also in economic categories). ART (Assessment of RFID Technology) method for evaluation of RFIDbased supply chain improvements based on business process modeling, multi-attribute decision making and reference models, will allow for rational choice of RFID application area in logistics of manufacturing companies. ART can be applied to:

- indicate process with the biggest RFID-based improvement potential,

- justify improvement of indicated process.

The main goal of a research is design of ART method, selection of tools, techniques and models to be used inside ART as well as its practical validation. ART should allow to:

- evaluate potential of RFID-based improvement of supply chain (strategy perspective),

- choose an area (process) for RFID-based improvement (tactics perspective),

- design new or improved ways of performing chosen processes (operations perspective),

- evaluate proposed RFID-based improvements (evaluation perspective).

Basing on above definition of ART author formulated research questions. The structure of ART and research questions is illustrated in Fig. 2.

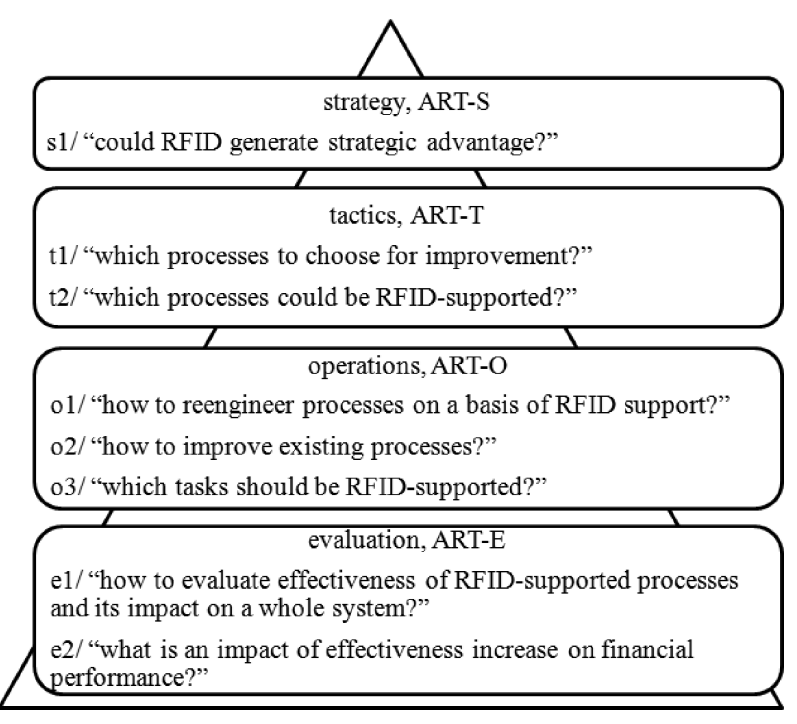

Fig. 2. Structure of ART and research question (source: own work).

\section{Main assumptions and research scope}

ART does not treat the problem of detailed economic effectiveness analysis. This is the problem succeeding ART method. ART outputs are guidelines for strategic decision and input for more detailed analysis. This will need detailed data extracted from tests, experiments, physical researches, etc. ART does not treat about details of RFID integration with existing cyber, physical, or cyber-physical systems. It is the outline for integration with business processes and basis for further analysis and implementation (integration with hardware, technologies, machines, IT).

ART is the method to rationalize early phases of RFID application decision making (see Fig. 2). Its positive output is green light for assigning resources to detailed analysis. It is also input and assumption for further detailed economic analysis and system engineering.

Author assumes that:

- choice of more than one process is possible,

- number of processes should be limited for transparency of method,

- ART will output ranking of processes and ranking will be based on RFID-based improvement potential,

- ART will be the tool for manufacturing companies to support and rationalize early phases of RFID application decision making,

- ART outputs will be input for further economic effectiveness analysis (e.g. ROI).

ART will be applicable for both internal and external supply chains. It will allow holistic and synthetic approach, but will need reference models for logistics. This will be developed using SCOR reference model. Research conducted in different branches and sectors showed substantial role of logistics (both external and internal) costs [37] (basing on A.T. Kearney data) e.g. proportion of logistics costs to machine industry sales equals $7.5 \%$, and $6.3 \%$ for consumption goods and media. Pfohl [38] emphasized that most companies forecast increase of logistics costs. Logistics has a big potential for savings. Many of logistics costs that impact final cost of goods are related to activities performed outside a factory, so both internal and external logistics costs are crucial for manufacturing companies.

\section{Assessment of RFID Technology}

An algorithm of ART method (see Fig. 3) is a sequence of top-down modules (from strategy through tactics and operations to evaluation). 


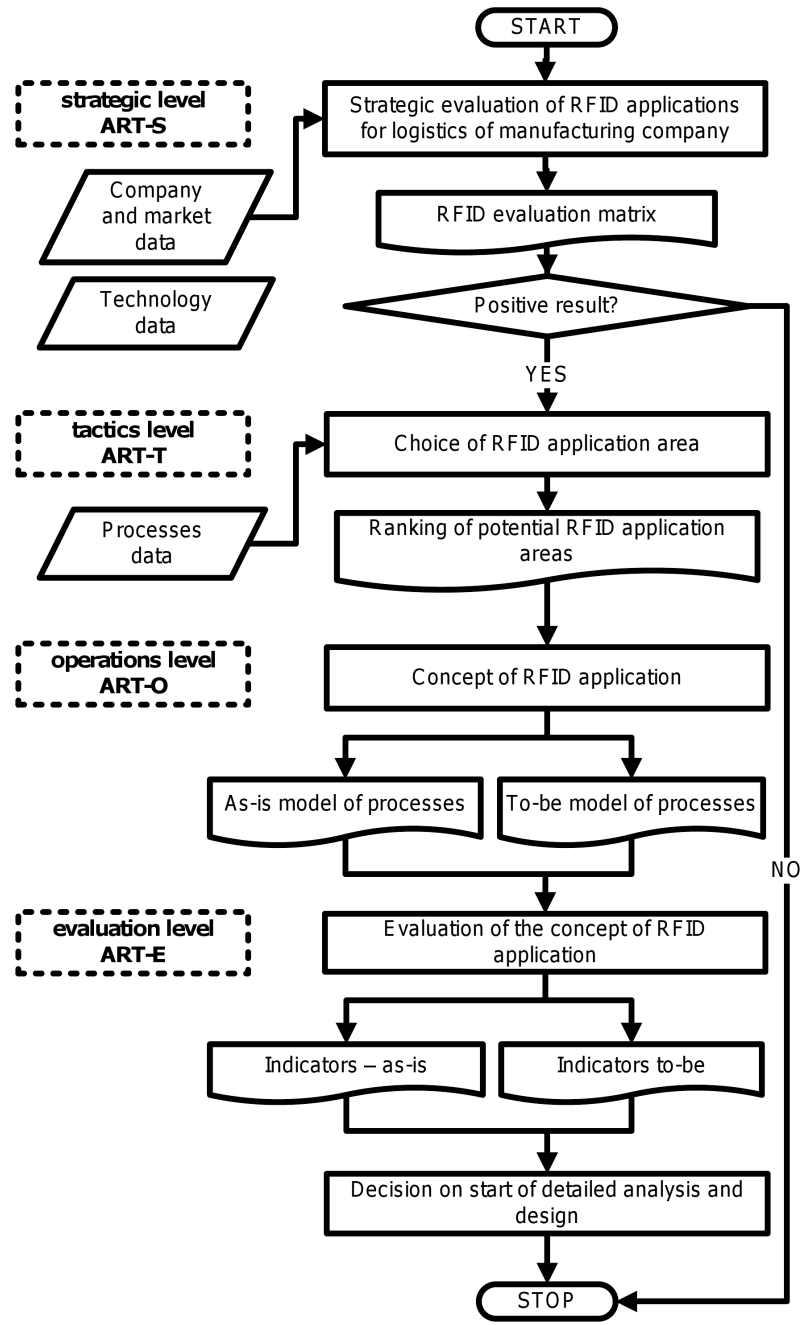

Fig. 3. General ART algorithm (source: own work).

Problems addressed in ART are described in Table 2. Specific tools will be used to solve listed topics. These tools are namely:

- Pfeiffer matrix for strategic evaluation of RFID $[39,40]-$ ART-S,

- Supply Chain Operations Reference (SCOR) [41] model (or company specific model if available and preferred) for as-is modeling and a base for defining possible applications - ART-T,

- fuzzy and group extension of Technique for Order of Preference by Similarity to Ideal Solution (TOPSIS) $[42,43]$ - for multiple attribute group decision making (MADM) based on expert linguistic evaluations of alternatives (possible RFID applications for logistics processes of a company) ART-T,

- linguistic scales for expert evaluations [43, 44] and fuzzy sets for mathematical representation of scales [45, 46] - ART-S and ART-T,

- software for business process modeling and simulation - ART-O and ART-E,
- interviews and questionnaires to gather data,

- approach for initial classification of RFID benefits [35] - ART-E.

Table 2

ART tools, techniques, models (source: own work).

\begin{tabular}{|c|c|}
\hline Main topics to solve & $\begin{array}{l}\text { Methods, models, tools, } \\
\text { techniques, ... }\end{array}$ \\
\hline \multicolumn{2}{|c|}{ ART-S } \\
\hline $\begin{array}{l}\text { Aspects to address: } \\
\text { - application volumes and } \\
\text { types } \\
\text { - attractiveness, } \\
\text { - diffusion potential, } \\
\text { - potential to create } \\
\text { strategic advantage } \\
\text { - technology maturity level } \\
\text { - company readiness level } \\
\text { - stakeholders needs } \\
\text { - financial and know-how re- } \\
\text { sources and stability }\end{array}$ & $\begin{array}{l}\text { Interviews and question- } \\
\text { naires } \\
\text { Expert evaluations } \\
\text { Linguistic scales } \\
\text { Fuzzy numbers } \\
\text { Technology portfolio - } \\
\text { Pfeiffer matrix } \\
\text { Guidelines for evaluation of } \\
\text { RFID, incorporation of cri- } \\
\text { teria listed in "remarks" }\end{array}$ \\
\hline \multicolumn{2}{|c|}{ ART-T } \\
\hline $\begin{array}{l}\text { Design of evaluation cri- } \\
\text { teria for potential RFID- } \\
\text { supported processes: } \\
\text { - feasibility } \\
\text { - attractiveness and poten- } \\
\text { tial for improvement } \\
\text { Choice of process for further } \\
\text { research }\end{array}$ & $\begin{array}{l}\text { Company-specific or ref- } \\
\text { erence (SCOR) process } \\
\text { models as a basis for def- } \\
\text { inition of potential RFID } \\
\text { applications } \\
\text { Business process mod- } \\
\text { elling (company-specific or } \\
\text { BPMN) } \\
\text { Interviews and question- } \\
\text { naires } \\
\text { Expert evaluations } \\
\text { Linguistic scales } \\
\text { Fuzzy numbers } \\
\text { MADM (TOPSIS) }\end{array}$ \\
\hline
\end{tabular}

\section{ART-O}

Design of as-is and to-be Company-specific or SCOR business process models as business process model representation of improve- Business process modelling ment concepts (or reengi- (BPMN or companyneering concepts) preferred)

Open-source computer aided modelling and simulation

Interviews and local visions of processes

\begin{tabular}{|c|c|}
\hline \multicolumn{2}{|c|}{ ART-E } \\
\hline $\begin{array}{l}\text { Increase of processes' effi- } \\
\text { ciency and its impact on } \\
\text { overall system efficiency } \\
\text { Comparison of as-is and to- } \\
\text { be indicators } \\
\text { List of benefits and its mea- } \\
\text { sures, indicators } \\
\text { Simulation of as-is and to-be } \\
\text { scenario and its indicators }\end{array}$ & $\begin{array}{l}\text { Open-source computer aid- } \\
\text { ed modelling and simulation } \\
\text { Simulations of as-is and to- } \\
\text { be scenarios } \\
\text { Interviews and local visions } \\
\text { of processes }\end{array}$ \\
\hline
\end{tabular}

\section{Illustrative example for ART-S}

Details of ART-S module were presented in [47]. ART-S research question is answered using technology portfolio method. Namely Pfeiffer matrix is pro- 
Management and Production Engineering Review

posed. Eversheim [48] proved its usefulness for evaluation of innovative technologies. Two attributes are evaluated: technology attractiveness and resources strength. Details of matrix are shown in Fig. 4.

Both main attributes are evaluated using scale from 0 to 1 by analogy to efficiency. Final attributes evaluations (OAT and OSZ) are rational numbers. Strategic recommendations based on OAT and OSZ are illustrated in Fig. 4.

RFID technology was evaluated by 2 experts. Internal company (responsible for logistics) expert and external RFID expert. Common evaluation of experts was agreed. Detailed questionnaire was prepared with 57 questions related to all 8 lowest-level Pfeiffer criteria (see Fig. 4). Questions serve as guideline for evaluations. Questionnaire is specific for supply chain of manufacturing company. All lowest-level criteria have equal weight. It is possible to modify algorithm and assign different weights.

Due to the objective alternatives uncertainty, human thought fuzziness and complexity of problem linguistics scales are used for qualitative expert evaluation. Decision environment is impossible to be clearly defined, especially at the early phases of alternatives evaluation. At this stage information is unquantifiable and approximate value is tolerable so according to [44] linguistics scales are proper mean to be used. Linguistic evaluations are uncertain and fuzzy, so fuzzy sets were used as representation of linguistic scales. Linguistic scale, consulted and agreed with RFID practitioners and surveyed company experts, is presented in Table 3 .
Table 3

Linguistic scale and fuzzy sets (source: own work).

\begin{tabular}{l|c}
\hline $\begin{array}{c}\text { Linguistic evaluation } \\
\text { of RFID application }\end{array}$ & $\begin{array}{c}\text { Triangular fuzzy number } \\
\left(l_{i}, m_{i}, u_{i}\right)\end{array}$ \\
\hline very low - VL & $(0 ; 0 ; 0.25)$ \\
\hline low - L & $(0 ; 0.25 ; 0.5)$ \\
\hline medium - M & $(0.25 ; 0.5 ; 0.75)$ \\
\hline high $-\mathrm{H}$ & $(0.5 ; 0.75 ; 1)$ \\
\hline very high $-\mathrm{VH}$ & $(0.75 ; 1 ; 1)$ \\
\hline
\end{tabular}

Evaluation guidelines were listed for each criterion. Exemplary guidelines for criterion "application volumes, types" $\left(\mathrm{AT}_{11}\right)$ are given in Table 4.

Table 4

Exemplary guidelines for evaluation of $\mathrm{AT}_{11}$ criterion (source: own work).

\begin{tabular}{l|l}
\hline VL & $\begin{array}{l}\text { No applications in competitors, other compa- } \\
\text { nies from same branch and stakeholders } \\
\text { No applications for areas critical for company } \\
\text { Need to develop completely new solutions } \\
\text { (from business logic point of view) }\end{array}$ \\
\hline $\mathrm{L}$ & $\ldots$ \\
\hline $\mathrm{M}$ & $\ldots$ \\
\hline $\mathrm{VH}$ & $\ldots$ \\
& $\begin{array}{l}\text { Applications in competitors, branch leaders } \\
\text { and stakeholders, whose strategic advantages } \\
\text { are based on RFID } \\
\text { Applications with universal and versatile char- } \\
\text { acteristics } \\
\text { Off-the-shelve solutions available (small need } \\
\text { of customizations) }\end{array}$ \\
\hline
\end{tabular}

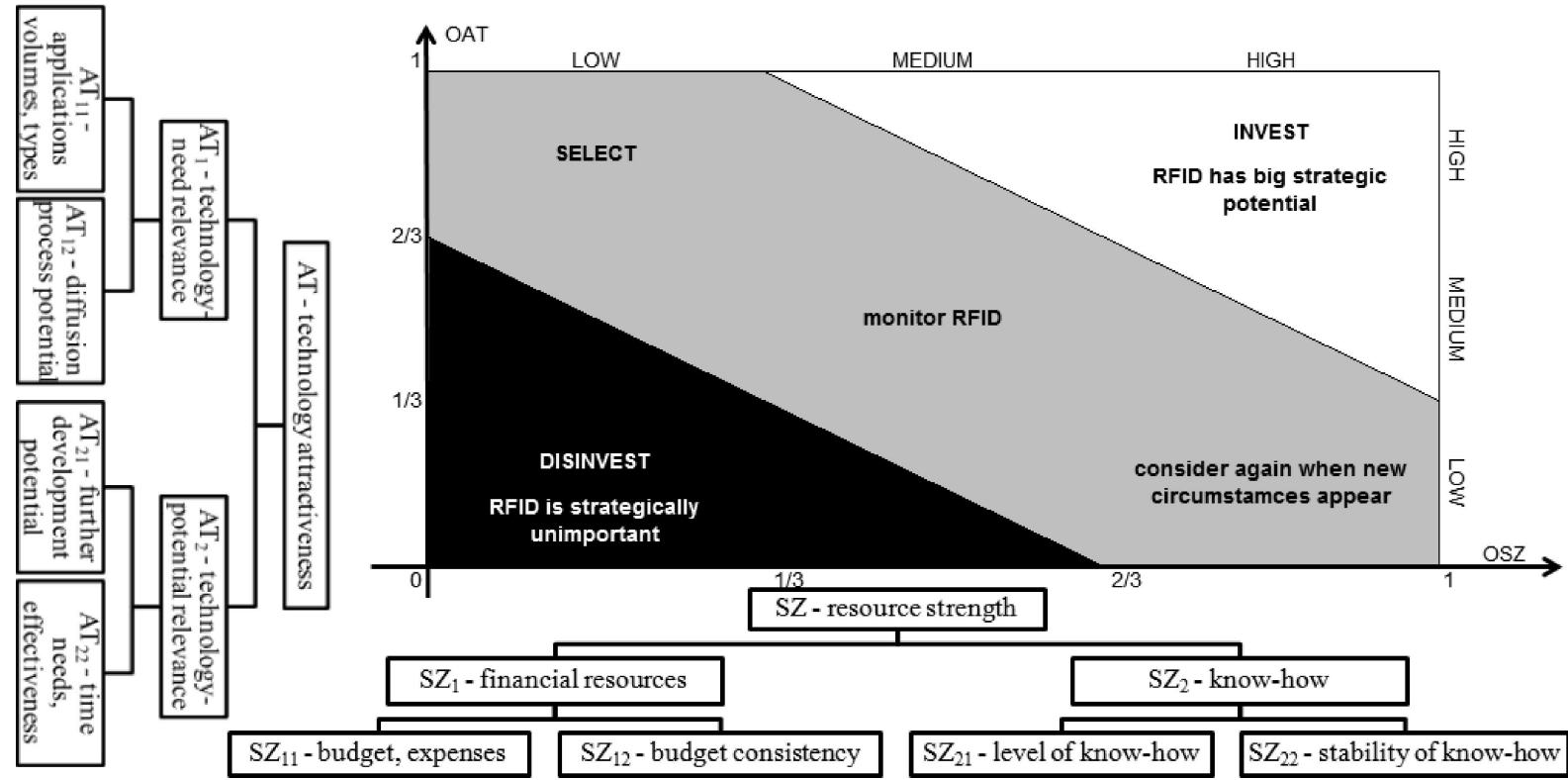

Fig. 4. Pfeiffer matrix (source: own work, based on [48]). 
Aggregated evaluation of technology attractiveness (AT) and resources strength (SZ) is mean of evaluations of lowest-level criteria (see Eqs. (1) and (2)). AT and SZ are triangular fuzzy numbers. Yager formula (see Eq. (3)) is used for defuzzification (calculation of crisp value - CV). Other defuzzification formulas were checked and did not create significant difference.

$$
\begin{gathered}
\sum_{i j} A T_{i j} /(i * j), \\
\sum_{i j} S Z_{i j} /(i * j), \\
C V=(l+2 m+u) / 4 .
\end{gathered}
$$

Table 5 shows data gathered from surveyed experts and calculation of AT and SZ crisp values. $\mathrm{AT}$ and $\mathrm{SZ}$ values interpretation (see Fig. 5) is that RFID is strategically important for a company and next ART module (ART-T) should be executed to find processes with the biggest potential for RFIDbased improvement (and/or reengineering). Details of ART-T module were presented in [49].

Table 5

Exemplary output of ART-S (source: own work).

\begin{tabular}{l|c|c|c|c|c|c|c}
\hline & $\mathrm{VL}$ & $\mathrm{L}$ & $\mathrm{M}$ & $\mathrm{H}$ & $\mathrm{VH}$ & $\begin{array}{c}\text { Fuzzy mean } \\
(l ; m ; u)\end{array}$ & $\begin{array}{c}\text { Crisp } \\
\text { value }\end{array}$ \\
\hline $\mathrm{AT}_{11}$ & & & & $\times$ & & & \multirow{2}{*}{$(0.56 ; 0.81 ; 0.94)$} \\
\hline $\mathrm{AT}_{12}$ & & & $\times$ & & & $\mathrm{OAT}=0.78$ \\
\hline $\mathrm{AT}_{21}$ & & & & & $\times$ & & \\
\hline $\mathrm{AT}_{22}$ & & & & & $\times$ & & \\
\hline $\mathrm{SZ}_{11}$ & & & & $\times$ & & & \multirow{2}{*}{$(0.5 ; 0.75 ; 1)$} \\
\hline $\mathrm{SZ}_{12}$ & & & & $\times$ & & $\mathrm{OSZ}=0.75$ \\
\hline $\mathrm{SZ}_{21}$ & & & & $\times$ & & & \\
\hline $\mathrm{SZ}_{22}$ & & & & $\times$ & & & \\
\hline
\end{tabular}

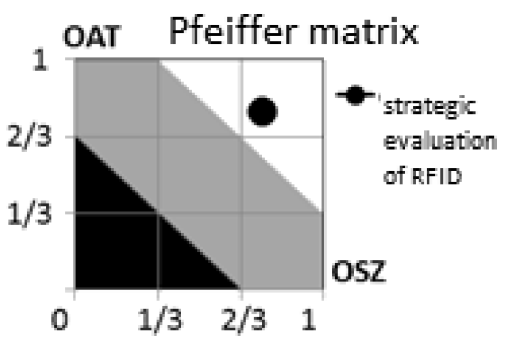

Fig. 5. Pfeiffer matrix for ART-S (source: own work).

\section{Research advancement, further steps and conclusion}

RFID systems are exemplification of Cyber Physical Systems. Strategic decision making on RFID implementation for logistics of manufacturing companies is the subject of presented research. Relations between elements of cyber and physical nature are substantial for RFID systems design. Assessment of RFID Technology (ART) method is proposed to address problems of strategic technology management related to the specific example of RFID implementation decision making. ART addresses problems directly related to cyber and physical aspects, as well as their connections.

Each of ART modules needs further clarification of algorithm and details. For each module separate detailed algorithm was constructed. Assessment of RFID Technology (ART) method was applied in environment of manufacturer of medical goods, but it is designed in a way to be applicable in any manufacturing company. Details of ART-S and ART-T with illustrative computational examples can be found in $[47,49]$. ART-O and ART-E modules were applied for the same company. ART application was successful and showed its big potential to be used at early phases of decision making process.

ART is divided into smaller modules for convenience. ART method is flexible in terms of techniques and tools used for solving problems and answering formulated questions. Author chose and showed that Pfeiffer matrix, SCOR, fuzzy sets, linguistic scales and TOPSIS are proper tools to solve problems related to formulated research questions. There were also specific sets of criteria and interview questions designed to gather data for ART modules. Those specific sets addresses cyber-physical nature of RFID systems.

Although ART utilizes several tools, it is easy in application at factory-level what was proved by good understanding and cooperation with surveyed experts. ART is supported by Excel spreadsheet, what enables easy correction of weights and matrixes to check impact of such changes on fuzzy TOPSIS results.

Proposed ART details were designed for the purpose of RFID evaluation for logistics of manufacturing company, but the method itself could be customized and applied also for other innovative technologies and early phases of decision making. ART method is the specific solution of more general problems related to technology management, as it was designed taking into account specifics of RFID technology and logistics processes.

Further research plans are threefold. Firstly, ART implementation in other manufacturing companies is planned. Secondly, different tools that can be used in ART (e.g. replacing TOPSIS with other decision making method) will be compared. Thirdly, generalization of ART and extension for other technologies will be proposed. 


\section{References}

[1] Schilberg D., How the Internet of Things Saves Lifes, IPv6 Business Conference, 2014, Zurich, online: http://bit.ly/1G2Lolt (accessed: 12th Oct 2014).

[2] Lee E.A., Cyber Physical Systems: Design Challenges, in ISORC, Orlando (FL), pp. 363-369, 2008.

[3] Yan L., Zhang Y., Yang L.T., Ning H., The Internet of Things: from RFID to the next-generation pervasive networked systems, Boca Ranton (FL): Auerbach Publications, 2008.

[4] Wan J., Chen M., Xia F., Li D., Zhou K., From Machine-to-Machine Communications towards Cyber-Physical Systems, ComSIS, 10, 3, 11051128,2013

[5] Chen G., Internet of Things towards Ubiquitous and Mobile Computing, Microsoft Research Asia Faculty Summit, Shanghai, 2010, online: http://research.microsoft.com/en-us/UM/redmond/events/asiafacsum2010/presentations/ Guihai-Chen_Oct19.pdf (accessed: 12th Oct 2014).

[6] PCAST, Report to the President and Congress: Designing a digital future: federally funded research and development in networking and information technology, 2010, online: http://www.whitehouse.gov/sites/default/files/microsites/ostp/pcast-nitrd-report-2010.pdf (accessed: 12th Oct 2014).

[7] Huebner A., Facchi C., Meyer M., Janicke H., RFID systems from a cyber-physical systems perspective, Proc. IEEE 11th WISES, Pilsen (Czech Republic), pp. 1-6, 2013.

[8] Wu N., Li X., RFID Applications in CyberPhysical System, Deploying RFID - Challenges, Solutions, and Open Issues, C. Turcu [Ed.], DOI:10.5772/17464: InTech, pp. 291-302, 2011.

[9] Gladysz B., RFID technology markets in Poland [in Polish: Rynki technologii RFID w Polsce], Ekonomika i Organizacja Przedsiebiorstw, 7, 32-41, 2012.

[10] Gladysz B., RFID technology markets in Poland (2014) [in Polish: Rynki technologii RFID w Polsce (2014)], Ekonomika i Organizacja Przedsiebiorstw, 5, 45-56, 2014.

[11] Dobkin D.M., The RF in RFID: UHF RFID in practice, 2nd ed., Oxford: Newnes, 2012.

[12] Finkenzeller K., RFID Handbook: fundamentals and applications in contactless smart cards and identification, New York (NY): John Wiley \& Sons, 2010.

[13] Sweeney P.J. II, RFID for dummies, Indianapolis (IN): Wiley Publishing, 2010.
[14] Larson P.D., Halldorsson A., Logistics versus supply chain: an international survey, Int. J. of Logistics Research and Applications, 7, 1, 17-31, 2004.

[15] Zelbst P.J., Green K.W., Sower V.E., Reyes P.M., Impact of RFID on manufacturing effectiveness and efficiency, Int. J. Oper. \& Prod. Manage., 32, 3, 329-350, 2012.

[16] Osyk B.A., Vijayaraman B.S., Srinivasan M., Dey A., RFID adoption and implementation in warehousing, Manage. Research Review, 35, 10, 904-926, 2012.

[17] Sarac A., Absi N., Dauzère-Pérès S., A literature review on the impact of RFID technologies on supply chain management, Int. J. Prod. Econ., 128, 1, 77-95, 2012.

[18] Bendavid Y., Lefebvre E., Lefebvre L.A., Fosso Wamba S., Key performance indicators for the evaluation of RFID-enabled B-to-B e-commerce applications. The case of a five-layer supply chain., Inform. Syst. and E-Business Manage., 7, 1, 1-20, 2009 .

[19] Savino M., Holimchayachotikul P., Brun A., SCOR model based on RFID enable supply chain management module on ERP, 4th SKIMA, Paro (Bhutan), pp. 228-235, 2010.

[20] Wei K.Q., Zheng L., Xiang Q., Chen X., Applications of RFID in a SCOR-model driven enterprise production system, IEEE 17th IE\&EM, Xiamen (China), pp. 501-505, 2010.

[21] Sobottka T., Leitner R., Sihn W., Methodology for the Development of RFID value added services to improve supply chain operation, Trans. FAMENA, $36,2,67-78,2012$.

[22] Leung J., Chu S.-C., Cheung W., Design research guidelines for mindful IT innovations: the case of RFID innovation in supply chain management, 46th HICSS, Wailea (Maui, HI), pp. 3727-3736, 2013.

[23] Li S., Godon D., Visich J.K., An exploratory study of RFID implementation in the supply chain, Manage. Research Review, 33, 10, 1005-1015, 2010.

[24] Lutton E., Skinner G., Regan B., RFID rationale and deployment methodology, 8th WSEAS, Venice, pp. 211-217, 2008.

[25] Becker J., Vilkov L.W.B., Winkelmann A., A model based approach for calculating the process driven business value of RFID investments, Int. J. Prod. Econ., 127, 2, 358-371, 2010.

[26] Bottani E., Rizzi A., Economical assessment of the impact of RFID technology and EPC system on the fast-moving consumer goods supply chain, Int. J. Prod. Econ., 112, 2, 548-569, 2008. 
[27] Wang S.-J., Liu S.-F., Wang W.-L., The simulated impact of RFID-enabled supply chain on pull-based inventory replenishment in TFT-LCD industry, Int. J. Prod. Econ., 112, 2, 570-586, 2008.

[28] Ha O.-K., Song Y.-S., Chung K.-Y., Lee K.-D., Park D., Relation model describing the effects of introducing RFID in the supply chain: evidence from the food and beverage industry in South Korea, Personal and Ubiquitous Computing, 18, 3, 553-561, 2014.

[29] Hardgrave B.C., Waller M., Miller R., Does RFID reduce out of stocks? A preliminary analysis, Fayetteville, ARK: ITRI UARK, 2005.

[30] Hardgrave B.C., Aloysius J., Goyal S., Does RFID Reduce Out of Stocks? A preliminary analysis, Int. J. of RF Technologies: Research and Applicat., 1, 1, 44-56, 2009.

[31] Ustundag A., Tanyas M., The impacts of Radio Frequency Identification (RFID) technology on supply chain costs, Transp. Research Part E, pp. 29-38, 2009 .

[32] Dai H., Tseng M.M., The impacts of RFID implementation on reducing inventory inaccuracy in a multi-stage supply chain, Int. J. Prod. Econ., 139, 2, 634-641, 2012.

[33] Attaran M., Critical Success factors and Challenges of Implementing RFID in Supply Chain Management, J. Supply Chain and Oper. Manage., 10, 1, 144-164, 2012.

[34] Lee I., Lee B.-C., An investment evaluation of supply chain RFID technologies: A normative modeling approach, Int. J. Prod. Econ., 125, 2, 313-323, 2010 .

[35] Bottani E., Volpi A., A SCOR-model based methodology to assess potential impact of RFID technology on logistic processes, Proc. RIRL, Pontremoli (Italy), pp. 118-129, 2006.

[36] Ugazio E., Pigni F., Measuring RFId benefits in the supply chain, Inf. Sys.: People, Organizations, Institutions, and Technologies, Berlin Heidelberg: Springer Physica-Verlag, pp. 469-476, 2010.

[37] Woźniak H., Logistics costs in modern economy (part 2) [in Polish: Koszty logistyczne we wspótczes- nej gospodarce (cz. 2)], Logistyka, pp. 32-36, June 2007.

[38] Pfohl H.Ch., CEE - Expansion des Einzelhandels Die logistische Herausforderung, Vienna, 2006.

[39] Pfeiffer W., Metze G., Schneider W., Amler R., Technologie-Portfolio zum Management strategischer Zukunftgeschäftsfelde, Göttingen: Vandenhoek \& Ruprecht, 1991.

[40] Pleschak F., Sabisch H., Innovationsmanagement, Stuttgart: Schäffer-Poeschel, 1996.

[41] Bolstoff P., Rosenbaum R., Supply chain excellence. A handbook for dramatic improvement using SCOR Model, Saranac Lake (NY): AMACOM, 2011.

[42] Hwang C.L., Yoon K., Multiple attribute decision making: methods and applications, New York, NY: Springer-Verlag, 1981.

[43] Chen S.J., Hwang C.L., Fuzzy multiple attribute decision making: methods and applications, Berlin Heidelberg: Springer-Verlag, 1992.

[44] Xu Z., Linguistic decision making. Theory and methods, Berlin Heidelberg: Springer Verlag, 2012.

[45] Zadeh L., Fuzzy sets, Information and Control, 8, 3, 338-353, 1965.

[46] Zimmermann H., Fuzzy sets theory and its applications, 2nd ed., Boston (MA): Kluwer Academic Publishers, 1991.

[47] Santarek K., Gladysz B., Strategic evaluation of RFID implementation effects [in Polish: Ocena strategiczna efektów wdrożenia RFID], Innovations in management and production engineering [in polish: Innowacje w zarządzaniu i inżynierii produkcji], vol. I, R. Knosala [Ed.], Opole: OW PTZP, pp. 191202,2014 .

[48] Eversheim W. [Ed.], Innovation Management for Technical Products, Aachen: Springer, 2009.

[49] Gladysz B., Santarek K., Fuzzy TOPSIS/SCORbased approach in assessment of RFID technology (ART) for logistics of manufacturing companies, Logistics Operations, Supply Chain Management and Sustainability, EcoProduction, P. Golinska [Ed.], Poznan: Springer, pp. 129-142, 2014. 